\title{
Esterase activity of Carbonic anhydrases serves as surrogate for selecting antibodies blocking Hydratase activity
}

Narasimha Rao Uda ${ }^{1 *}$, Volker Seibert ${ }^{2}$, Frank Stenner ${ }^{1,3}$, Philipp Müller ${ }^{1}$, Petra Herzig ${ }^{1}$, Gabor Gondi ${ }^{4,5}$, Reinhard Zeidler ${ }^{4,5}$, Marc van Dijk ${ }^{2}$, Alfred Zippelius ${ }^{1,3}$, Christoph Renner ${ }^{1 *}$

\section{Supporting information}

The enzymes (CA9 \& CA12) were titrated with substrate ( $p N P A)$ from $0.3 \mathrm{mM}$ to $35 \mathrm{mM}$ in acetone due to very limited solubility of $p$ NPA in aqueous solution (1-4) in the absence or presence of $0.3 \mu \mathrm{M}$ AZA, which is greater than the $K_{\mathrm{d}}$ value of AZA $(0.02 \mu \mathrm{M}$ for CA2 and $0.04 \mu \mathrm{M}$ for CA4) $(5,6)$. The $V_{\max }, K_{\mathrm{m}}$ and the apparent $K_{\mathrm{m}}\left(K_{\mathrm{m}}{ }^{\text {app }}\right)$ were calculated according to the Michaelis-Menten equation, curves were plotted using least squares non-linear fitting in Prism6 software (Figure S1). As expected for a competitive inhibitor (7-11), the inhibitor (AZA) increases the measured apparent $K_{\mathrm{m}}$ without affecting the $V_{\max }$ to a great extent. The $K_{\mathrm{m}}$ values are normally high for the esterase activity of carbonic anhydrases and in agreement with the published data for other CA isoforms $(5,12,13)$. The standard deviation of $K_{\mathrm{m}}{ }^{\text {app }}$ is very high and cannot be measured accurately under these experimental conditions, i.e. high AZA concentration $(0.3 \mu \mathrm{M})$ and at the same time not being able to reach the saturating concentrations of the substrate due to limited solubility. From the $K_{\mathrm{m}}$ and $K_{\mathrm{m}}{ }^{\text {app }}$ values, the inhibition constant $\left(K_{\mathrm{i}}\right)$ was derived using the Michaelis-Menten equation, $K_{\mathrm{m}}{ }^{\text {app }}=K_{\mathrm{m}}(1+$ $\left.[\mathrm{I}] / K_{\mathrm{i}}\right)$ ). Kinetic and inhibition data are summarized in table S2. Esterase $K_{\mathrm{i}}$ values $26 \mathrm{nM}$ (CA9) and $12.5 \mathrm{nM}$ (CA12) are comparable with the published hydratase $K_{\mathrm{i}}$ values of CA9 (14) and CA12 (15).

The esterase activity of Carbonic anhydrases is in general very slow and requires high concentration of enzyme to perform the enzymatic assay $(6,16)$. Here we presented the esterase enzyme activity of CA9 and CA12, which cannot be reliably detectable at a final concentration lower than $0.025 \mu \mathrm{M}$ (Figure S3). Therefore, four times higher concentrations of CA9 $(0.093 \mu \mathrm{M})$ and CA12 $(0.114 \mu \mathrm{M})$ have been implemented for all the assays in order to facilitate robust quantification of the inhibition. 


\section{References}

1. Pocker Y, Miao CH. Molecular basis of ionic strength effects: interaction of enzyme and sulfate ion in $\mathrm{CO} 2$ hydration and HCO3- dehydration reactions catalyzed by carbonic anhydrase II. Biochemistry. 1987 Dec 15;26(25):8481-6. PubMed PMID: 3126803.

2. Pocker Y, Janjic N. Enzyme kinetics in solvents of increased viscosity. Dynamic aspects of carbonic anhydrase catalysis. Biochemistry. 1987 May 5;26(9):2597606. PubMed PMID: 3111530.

3. POCKER Y, STONE J. CATALYTIC VERSATILITY OF ERYTHROCYTE CARBONIC ANHYDRASE .3. KINETIC STUDIES OF ENZYME-CATALYZED HYDROLYSIS OF PNITROPHENYL ACETATE. Biochemistry. 1967 1967;6(3):668-\&. PubMed PMID: WOS:A19679029400005. English.

4. Verpoorte JA, Mehta S, Edsall JT. Esterase Activities of Human Carbonic Anhydrases B and C. Journal of Biological Chemistry. 1967 September 25, 1967;242(18):4221-9.

5. Baird TT, Waheed A, Okuyama T, Sly WS, Fierke CA. Catalysis and Inhibition of Human Carbonic Anhydrase IV†. Biochemistry. 1997 1997/03/01;36(9):266978.

6. Iyer R, Barrese AA, 3rd, Parakh S, Parker CN, Tripp BC. Inhibition profiling of human carbonic anhydrase II by high-throughput screening of structurally diverse, biologically active compounds. Journal of biomolecular screening. 2006 Oct;11(7):782-91. PubMed PMID: 16858005.

7. Abbate F, Winum JY, Potter BV, Casini A, Montero JL, Scozzafava A, et al. Carbonic anhydrase inhibitors: X-ray crystallographic structure of the adduct of human isozyme II with EMATE, a dual inhibitor of carbonic anhydrases and steroid sulfatase. Bioorg Med Chem Lett. 2004 Jan 5;14(1):231-4. PubMed PMID: 14684333.

8. Abbate F, Coetzee A, Casini A, Ciattini S, Scozzafava A, Supuran CT. Carbonic anhydrase inhibitors: X-ray crystallographic structure of the adduct of human isozyme II with the antipsychotic drug sulpiride. Bioorg Med Chem Lett. 2004 Jan 19;14(2):337-41. PubMed PMID: 14698154.

9. Abbate F, Casini A, Scozzafava A, Supuran CT. Carbonic anhydrase inhibitors: Xray crystallographic structure of the adduct of human isozyme II with a topically acting antiglaucoma sulfonamide. Bioorg Med Chem Lett. 2004 May 3;14(9):2357-61. PubMed PMID: 15081040.

10. Abbate F, Casini A, Owa T, Scozzafava A, Supuran CT. Carbonic anhydrase inhibitors: E7070, a sulfonamide anticancer agent, potently inhibits cytosolic isozymes I and II, and transmembrane, tumor-associated isozyme IX. Bioorg Med Chem Lett. 2004 Jan 5;14(1):217-23. PubMed PMID: 14684331.

11. Safarian S, Bagheri F, Moosavi-Movahedi AA, Amanlou M, Sheibani N. Competitive inhibitory effects of acetazolamide upon interactions with bovine carbonic anhydrase II. Protein Journal. 2007 Sep;26(6):371-85. PubMed PMID: WOS:000249211700002. English.

12. Zastrow ML, Peacock AF, Stuckey JA, Pecoraro VL. Hydrolytic catalysis and structural stabilization in a designed metalloprotein. Nature chemistry. 2012 Feb;4(2):118-23. PubMed PMID: 22270627. Pubmed Central PMCID: 3270697.

13. Krebs JF, Ippolito JA, Christianson DW, Fierke CA. Biol Chem. 1993;268:27458.

14. Ilies MA, Vullo D, Pastorek J, Scozzafava A, Ilies M, Caproiu MT, et al. Carbonic anhydrase inhibitors. Inhibition of tumor-associated isozyme IX by 
halogenosulfanilamide and halogenophenylaminobenzolamide derivatives. J Med Chem. 2003 May 22;46(11):2187-96. PubMed PMID: 12747790.

15. Vullo D, Innocenti A, Nishimori I, Pastorek J, Scozzafava A, Pastorekova S, et al. Carbonic anhydrase inhibitors. Inhibition of the transmembrane isozyme XII with sulfonamides-a new target for the design of antitumor and antiglaucoma drugs? Bioorg Med Chem Lett. 2005 Feb 15;15(4):963-9. PubMed PMID: 15686894.

16. Banerjee AL, Swanson M, Roy BC, Jia X, Haldar MK, Mallik S, et al. Protein surfaceassisted enhancement in the binding affinity of an inhibitor for recombinant human carbonic anhydrase-II. J Am Chem Soc. 2004 Sep 8;126(35):10875-83. PubMed PMID: 15339172. 
Figures \& Table for Supporting information

Figure S1: Esterase activity of CA9 (A) and CA12 (B) at different concentrations of the substrate

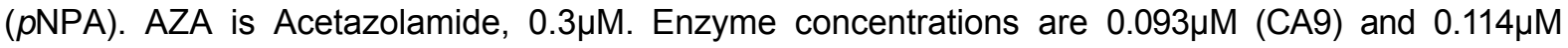
(CA12). Final concentration of acetone in the reaction is $10 \%(\mathrm{~V} N)$ for substrate concentrations from $0.3 \mathrm{mM}$ to $23 \mathrm{mM}$ and $20 \%$ at $29 \mathrm{mM}$ and $35 \mathrm{mM}$ substrate concentrations. The data is representative of two independent experiments in triplicates.
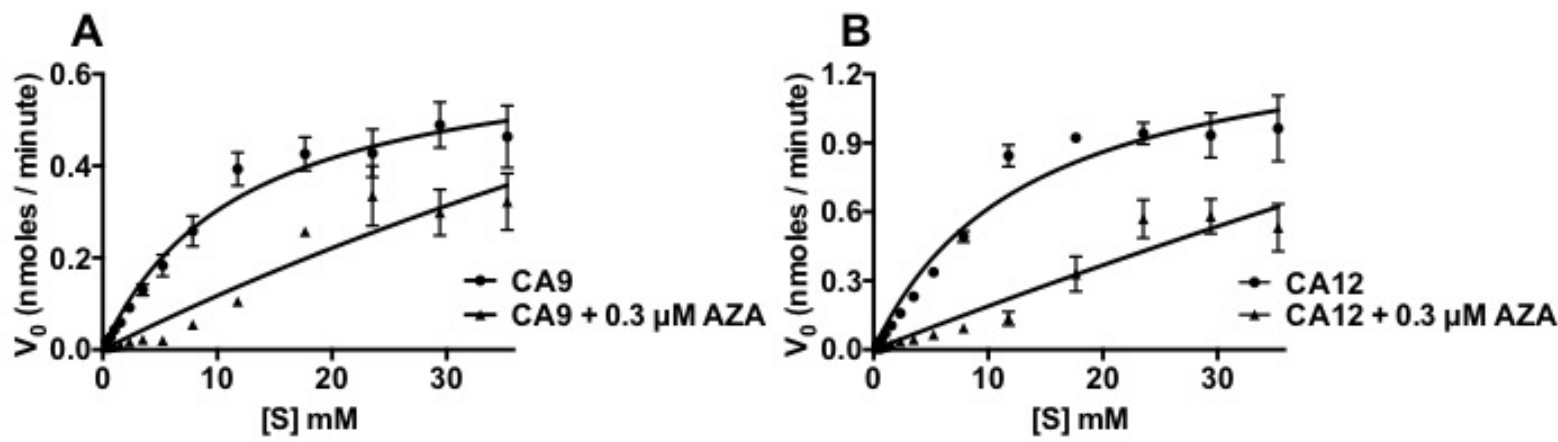

Table S2: Kinetic and inhibition data of CA9 and CA12 esterase activity. Substrate ( $p$ NPA) concentrations range from $0.3 \mathrm{mM}$ to $35 \mathrm{mM}$. AZA is Acetazolamide, $0.3 \mu \mathrm{M}$. Enzyme concentrations are $0.093 \mu \mathrm{M}(\mathrm{CA} 9)$ and $0.114 \mu \mathrm{M}(\mathrm{CA} 12)$.

\begin{tabular}{cccccc}
\hline & $\begin{array}{c}\text { With } 0.3 \mu \mathrm{M} \text { AZA } \\
\boldsymbol{V}_{\max }\end{array}$ & $\begin{array}{c}\boldsymbol{V}_{\text {max }} \text { app } \\
(\text { nmoles/minute) }\end{array}$ & $\begin{array}{c}\boldsymbol{K}_{\mathbf{m}} \\
(\mathrm{mM})\end{array}$ & $\begin{array}{c}\text { With } 0.3 \mu \mathrm{M} \text { AZA } \\
\boldsymbol{K}_{\mathbf{m}} \text { app } \\
(\mathrm{mM})\end{array}$ & $\begin{array}{c}\text { AZA } \\
\boldsymbol{K}_{\mathbf{i}} \\
(\mathrm{nM})\end{array}$ \\
CA9 & $0.67 \pm 0.04$ & $1.88 \pm 01.56$ & $12.05 \pm 1.59$ & $150.2 \pm 146.5$ & 26.18 \\
CA12 & $1.44 \pm 0.09$ & $6.53 \pm 11.43$ & $13.43 \pm 2.04$ & $335.3 \pm 634.3$ & 12.52 \\
\hline
\end{tabular}

Figure S3: Esterase activity (1 mM pNPA) at different concentrations of CA9 (A) and CA12 (B) over time. The data is representative of two independent experiments in triplicates. $p N P$ is para Nitrophenyl over time.

A

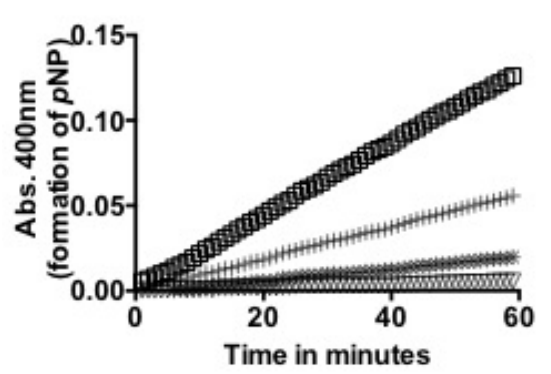

B

口 $0.2 \mu \mathrm{MCA} 9$

$+0.1 \mu \mathrm{M}$ CA9

* $0.05 \mu \mathrm{M}$ CA 9

$\nabla 0.025 \mu \mathrm{M} \mathrm{CA} 9$

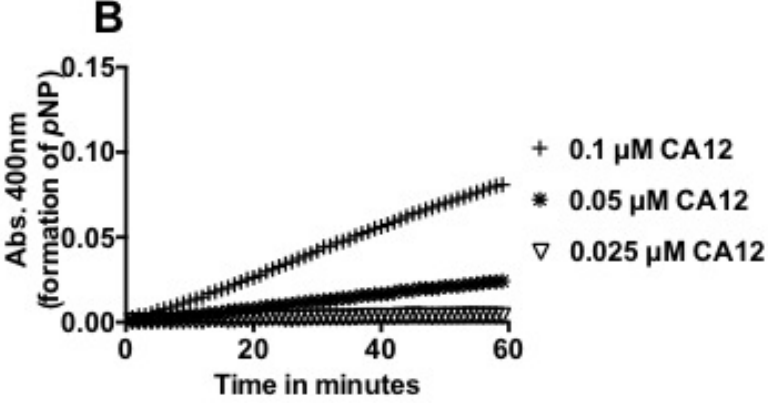

